Vidyodaya J., of Sci., (1992) Vol.4, No. 1, pp: 219 - 232

\title{
GROWTH ASSESSMENT OF SOME ORNAMENTAL FISH SPECIES FED WITH LOW COST FEEDS
}

\author{
W. A. D. Mahaulpatha, A. De Alwis and J. Jinadasa \\ Department of Zoology, \\ University of Sri Jayewardenepura, \\ Nugegoda, Sri Lanka.
}

\begin{abstract}
Three feeds were formulated using low cost raw materials with protein contents ranging from $44 \%-62 \%$ and prepared in the laboratory and were tested against an imported feed (protein $32 \%$ ) on young stages (initial weight, $0.03-0.71 \mathrm{~g}$.) of four species of ornamental fish namely, Rosy Barb (Barbus conchonius), Angel (Pterophyllum scalure), Gold fish (Carassius auratus auratus) and Goggle - eye (Carassius sp.) cver a period of 2 months to assess the feasibility of using locally prepared feeds in rearing of very young stages in ornamental fish culture.

High Assimilation Efficiencies (56-82\%), low Food Conversion Ratios (less thae 2), high Growth Rates (0.005) $-0.02 \mathrm{~g}$. day ${ }^{-1}$ ) and high Survival Rates $(93 \%-100)$ shown by all species on the prepared diets proved the locally prepared feeds to be highly acceptable.

The results also reveal that there is an optimal level of dietary protein requirement in the range of $44-50 \%$ for three of the four species studjed.

The study also showed that the cost of feeds can be reduced by

(a) using low cost protein sources such as shrimp heads, fish/meat offals, rice bran and soya flour;

(b) using more carbohydrates with less protein.
\end{abstract}

Key Words: Ornamental fish, Growth, low-cost dirt, Cheap protein sources, Optimum requirement of protein, Carbohydrates and Fibre

\section{Introduction}

During the last four decades there has been a considerable growth and diversification in the international trade of ornamental fish.

The demand for tropical fish arises from the developed countries such as the USA and Japan which are the major importers of marine and freshwater ornamental fish and invertebrates. Sri Lanka's export market of tropical fish to Singapore, as well as to the USA and Japan, is growing at a rapid rate. 
There are 17 live-fish exporters registered in the Association of Live Fish Exporters of Sri Lanka (Anэn., 1992). However there are many other exporters who are not registered in this Association. There are also thousands of small scale fish breeders catering these dealers. About 30 different varieties are bred for export and local markets (Anon, 1990). With the present varieties of fish being bred commercially, there is an urgent need for feeds which are economical, safe and nutritious.

Feed of ornamental fish can be categorised into natural (live) and formulated food. The ornamental fish fry/fingerling mainly thrive on live food such as blood worms (Chironomus larvae), Artermia (Artemia salina) and micro worms (Anguilula silusiae). An undesirable artificial feed may result in stunted growth and high mortalities in fish during these very early stages. Therefore, fish breeders are dependent on live focd for these early stages. However, it has become increasingly difficult to obtain live food and also the costs have risen very high (eg: a $100 \mathrm{~g}$. of local variety of Artemia is Rs 100/,while an imported variety costs Rs. 200/- -250/-) making the fry/fingerling stage very critical in ornamental fish rearing. In addition, commercial breeders also import fish feeds for adult fish at very high cost (eg. a $100 \mathrm{~g}$. of fish pellet is rupees 24/-) leading to a poor return of their investment. These two factors emphasise the need of formulating suitable artificial feeds locally, for fry/fingerling and adult stages to substitute the natural live food as well as imported high cost artificial feeds.

Much work remains to be done before the food requirements of ornamental fish could be established. Little has been carried-out in this respect in Sri Lanka (Vijayaraghavan et.al, 1985). More attention has been paid to feeds suitable for edible species (De Silva and Perera 1985.; Chandrasoma and Siriwardene, 1988).

Success in popularising local fish feeds depends on low cost, long shelf-life and on the possibility of preparing them domestically with the help of very simple equipment. These aspects have not received due consideration and experimentation in Sri Lanka.

Present study was an attempt to formulate and produce suitable feeds for very young stages of ornamental fish, using low cost raw materials, simple equipment and a simple procedure by which a long shelf-life is ensured and evaluating their suitability for various species of fish.

\section{Materials and methods}

Three laboratory feeds (F1, F2 and F3) were prepared in the Department of Zoology, University of Sri Jayewardenepura following three modified formulae used for low cost shrimp feeds (Primavera, 1982; Brchmanonda and Sahavacharin, 1984; De Alwis et. al., 1988). These three feeds and an 
imported feed (F4) (as a control) were tried on four species of popular ornamental fish, namely, Rosy Barb (Barbus conchonius: Family: Cyprinidae), Angel (Pterophyllum scalare: Family: Cichlidae), Gold fish (Carassius auratus auratus: Family: Cyprinidae) and Goggle-eye (Carassius sp.; Family: Cyprinidae), over a period of 2 months to assess the suitability of the formulated feeds F1, F2, F3 as fry/finger- ling feeds in ornamental fish rearing. This experiment was conducted from May to September 1991 at the Department of Zoology, University of Sri Jayewardenepura.

Ingredients used in the three laboratory prepared feeds are given in Table I and the method ology of feed preparation is given in Appendix $I$.

Thirty samples from each laboratory prepared feeds were stored using two most common domestic methods (eg. refrigeration and at room temperature) of storing as follows to determine the shelf-life;

a) Five samples at room temperature in sealed plastic bags

b) Five samples at room temperature in air-tight containers

c) Five samples at room temperature in open containers

d) Five samples under refrigeration in air-tight containers

e) Five samples under refrigeration in open containers

f) Five samples under refrigeration in sealed plastic bags

Observations made on shelf-life of feeds are given in Table II.

Clean, all-glass tanks $(90 \times 30 \times 30 \mathrm{~cm})$ filled with 30 litres of chlorine free, aged water were used in these experiments. The experimental tanks were maintained under laboratory temperatures $\left(24-29^{\circ} \mathrm{C}\right)$ with constant aeration. One third of water in each tank was replaced once in two weeks throughout the experimental pericd. After each water change water quality assessments were mads (Table III). These included parameters such as temperature, hardness, $\mathrm{pH}$ and dissolved oxygen concentration. The stocking rates of fish were maintained at 30 fish per tank on the basis of one fish (less than 1") per litre of water. Initial lengths and weights of random samples of 10 fish from each tank were recorded under anaesthesia [by putting the fish in water containing $100 \mathrm{mg}$. of MS222 (4 Amino-benzoesaure-ethylester-PURAN) per litre of water] before introducing them to tanks. Each feed was tested on the four species of fish in duplicate.

Dried pellets were ground using a mortar and pestle to obtain suitable particle sizes and the fish were fed thrice a day $(8.00 \mathrm{am}, 1.00 \mathrm{pm}$ and $4.00 \mathrm{pm})$ at the rate of $5 \%$ bcdy weight per day (Bardach et. al, 1972). Total amount of feed given was recorded. 
Faecal matter deposited on the bottom within a period of 24 hours was collected by siphoning with a plastic tube before the first meal. The faeces was dried at $75^{\circ} \mathrm{C}$ for 24 hours and weighed.

At the end of 2nd month total number of fish survived was counted and lengths and weights were recorded. They were used in the determination of proximate composition of body muscles.

The crude protein content of feeds and body muscles of fish was determined by the Semi Micro Kjeldhal method and the total lipid was determined by the anhydrous ether method in a Soxlet Apparatus. The ash content was determined by the conventional method by burning in a Muffe furnace at $550^{\circ} \mathrm{C}$. Crude fibre content of feeds was determined by Acid Detergent Mixture method. Results of proximate composition of feeds and body muscles of fish (protein, lipid and ash only) are given in Tables IV and V respectively.

Gain in weight per day and Food Conversion Ratio (Growth Coefficient Ratio/Focd quotient/Nutritive Ratio) were taken as indices of growth and were calculated according to Clark et. al., 1989.

Assimilation Efficiency was taken as an indicator of readily assimilable form of focd and was calculated according to Clark et. al., 1989.

Results of the above are given in Tables VI. 1 - VI.4 and the growth rates are also shown in Fig. 1.

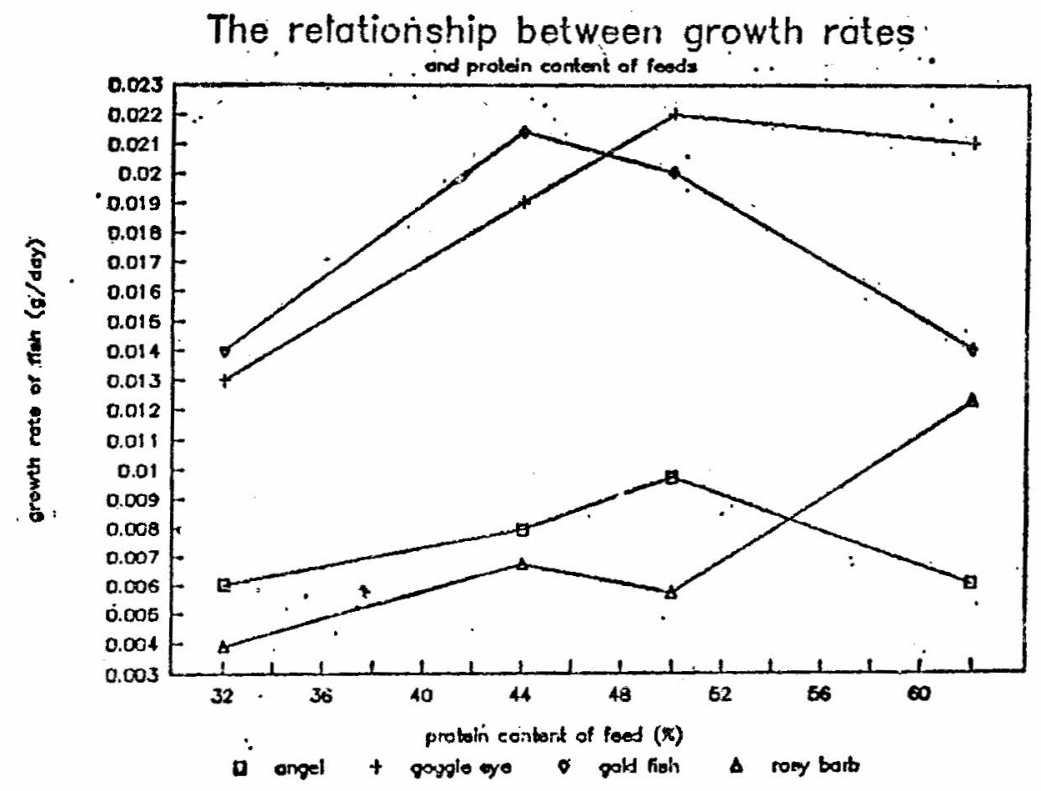

Fig. 1. The relationship between growth rates of fish and the protein contents of feeds. 
Growth rates were compared by one-way analysis of variance (ANOV) (Zar, 1974). Differences between feeds were analysed for significance by $(\mathrm{P}<0.05)$ using the Ducans test. (Balley, 1965).

Cost of feeds were calculated on per kilo basis taking into consideration the following recurrent expenditure;
a) raw material cost
b) labour cost
c) electricity cost
d) transport cost

Equipment cost was not considered as it is a capital expenditure. Details of the costs is given in Appendix II and the cost analysis is given in Table VII.

Table I Ingredients used and their percentage composition

\begin{tabular}{|c|c|c|c|}
\hline Feed ingredients & Feed $F 1 \%$ & Feed $F 2 \%$ & Feed $F 3 \%$ \\
\hline Meat offal (wet) & - & 17 & - \\
\hline Fish meal & 28 & 17 & 52 \\
\hline Shrimp head & 13 & - & 5 \\
\hline Rice bran & 14 & 25 & 25 \\
\hline Soya flour & 13 & - & 10 \\
\hline Wheat flour & 14 & 18 & - \\
\hline Carrot leaves & - & 17 & 5 \\
\hline Ipil ipil & 12 & - & - \\
\hline *Mineral mixture & 1 & 1 & \\
\hline Yeast & - & - & 1 \\
\hline ***Mult ivitamin & 1 & 0.5 & 0.5 \\
\hline Vit.C & 1 & - & 0.5 \\
\hline Vit.E & - & 0.5 & \\
\hline Cod liver oil & - & - & 1 \\
\hline Poonac & 3 & 2 & - \\
\hline Fish liver (wet) & - & 2 & - \\
\hline
\end{tabular}

*Mineral-Pecutrin-Calcium 10.8\%, Phosphorous 10\%, Ca:P $=1.68: 1 \mathrm{Zn}$ : $\mathrm{Mn}: \mathrm{Fe}: \mathrm{Cu}=2: 4: 1: 1$, Magnesium 2\%, Salt $6 \%$, Trace elements, Vit E, Vit $\mathrm{K} 2 \%$, Vit D3 and Vit B2.

**Multivitamin-Vit A2000 iu, vit, D2 200 iu, Vit B1 $1 \mathrm{mg}$, Vit B2 $1.2 \mathrm{mg}$, Vit B8 $0.08 \mathrm{mg}$, Dpanthenol $2 \mathrm{mg}$, Nicinamide $10 \mathrm{mg}$, Vit C $30 \mathrm{mg}$, Vit B12 $1 \mathrm{mg}$, Vit E $0.2 \mathrm{mg}$. 
Table II Observations on shelf-life of three prepared feeds

\begin{tabular}{|c|c|c|c|c|}
\hline $\begin{array}{l}\text { Method of storing } \\
\text { (Feed F1, F2, F3) }\end{array}$ & $\begin{array}{l}\text { Tested } \\
\text { time for } \\
\text { Shelf life }\end{array}$ & \multicolumn{3}{|c|}{ Remarks } \\
\hline $\begin{array}{l}\text { In sealed plastic bags } \\
\text { at room temperature }\end{array}$ & 6 months & \multicolumn{3}{|c|}{ All samples remained intact } \\
\hline $\begin{array}{l}\text { In sealed plastic bags } \\
\text { under refrigeration }\end{array}$ & 9 months & \multicolumn{3}{|c|}{$\begin{array}{l}\text { All samples remained intact } \\
\text { for } 6 \text { months }\end{array}$} \\
\hline $\begin{array}{l}\text { In air tight containers } \\
\text { at room temperature }\end{array}$ & 6 months & \multicolumn{3}{|c|}{$\begin{array}{l}\text { All samples remained intact } \\
\text { for } 6 \text { months }\end{array}$} \\
\hline $\begin{array}{l}\text { In air tight containers } \\
\text { under refrigeration }\end{array}$ & 6 months & \multicolumn{3}{|c|}{$\begin{array}{l}\text { All samples remained intact } \\
\text { for } 6 \text { months }\end{array}$} \\
\hline $\begin{array}{l}\text { In open container } \\
\text { under refrigeration }\end{array}$ & 6 months & $\begin{array}{l}\text { Feed F1 remained } \\
\text { intact for } 60 \text { days } \\
\text { a fungus appeared } \\
\text { on } 61 \text { st day. But } \\
\text { got completely } \\
\text { spoilt by } 65 \text { th } \\
\text { day }\end{array}$ & $\begin{array}{l}\text { Feed F2 } \\
\text { remained intact } \\
\text { for } 28 \text { days and } \\
\text { a fungus appear } \\
\text { ed on the } 29 \text { th } \\
\text { day. Got comple } \\
\text { tely spoilt by } \\
37 \text { th day. }\end{array}$ & $\begin{array}{l}\text { Feed F3 } \\
\text { remained intact } \\
\text { for 50days and } \\
\text { a fungus appear } \\
\text { ed on the } 51 \text { st } \\
\text { day. Got complet } \\
\text { ely spoilt by } \\
55 \text { th day. }\end{array}$ \\
\hline $\begin{array}{l}\text { In open container } \\
\text { at room temperature }\end{array}$ & 6 months & $\begin{array}{l}\text { Feed F1 } \\
\text { remained intact } \\
\text { for } 18 \text { days and } \\
\text { a fungus appea- } \\
\text { ed on the } 19 \text { th } \\
\text { day. Got comple } \\
\text { tely spoilt by } \\
\text { 26th day }\end{array}$ & $\begin{array}{l}\text { Feed F2 } \\
\text { remained intact } \\
\text { for } 7 \text { days and } \\
\text { a fungus appea- } \\
\text { ed on the 8th } \\
\text { day. Got comple } \\
\text { tely spoilt by } \\
\text { 13th day. }\end{array}$ & $\begin{array}{l}\text { Feed F3 } \\
\text { remained intact } \\
\text { for } 15 \text { days and } \\
\text { a fungus appea- } \\
\text { ed on the } 16 \mathrm{th} \\
\text { day. Got complet } \\
\text { ely spoilt by } \\
22 \text { d day. }\end{array}$ \\
\hline
\end{tabular}

Table III Water quality observed in experimental tanks during the study period.

\begin{tabular}{l|l}
\hline $\begin{array}{l}\text { Environment } \\
\text { parameter }\end{array}$ & Range \\
\hline $\begin{array}{l}\text { Temperature (C) } \\
\text { pH }\end{array}$ & $\begin{array}{l}24-27 \\
\text { Water hardiess } \\
\text { (m.mol/1) }\end{array}$ \\
$\begin{array}{l}\text { Oxygen } \\
\text { (ppm.) }\end{array}$ & $0.48-0.5$ \\
\hline
\end{tabular}


Table IV Proximate composition of four feeds

\begin{tabular}{l|c|c|c|c|c|c}
\hline Feed & Moisture & Protein & Lipid & Fibre & Ash & $\begin{array}{c}\text { Carbo- } \\
\text { hydrate } \\
\%\end{array}$ \\
\hline & $\%$ & $\%$ & $\%$ & $\%$ & $\%$ & $\%$ \\
$\mathrm{~F}_{1}$ & 7 & 44 & 8 & 17 & 13 & 11 \\
$\mathrm{~F}_{2}$ & 6 & 50 & 9 & 11 & 10 & 14 \\
$\mathrm{~F}_{3}$ & 7 & 62 & 10 & 7 & 6 & 8 \\
$\mathrm{~F}_{4}$ & 8 & 32 & 6 & 4 & 4 & 46 \\
\hline
\end{tabular}

Table V Proximate composition of fish body muscles

( $\%$ wet weight basis)

$\begin{array}{llll}\text { F1 - protein } 44 \% & : \text { carbohydrate } & 11 \% \\ \text { F2 } & \text { protein } 50 \% & : \text { carbohydrate } & 14 \% \\ \text { F3 - protein } 62 \% & : \text { carbohydrate } & 8 \% \\ \text { F4 - protein } 32 \% & : \text { carbohydrate } & 46 \%\end{array}$

\begin{tabular}{|c|c|c|c|c|c|}
\hline & & & FEED & & \\
\hline Fish sp. & Contents & $F_{1}$ & $F_{2}$ & $F_{3}$ & $F_{4}$ \\
\hline Angel & $\begin{array}{l}\text { Protein } \\
\text { Ash } \\
\text { Lipid }\end{array}$ & $\begin{array}{c}22.173 \\
4.25 \\
16.02\end{array}$ & $\begin{array}{c}24.8 \\
5.89 \\
15.7\end{array}$ & $\begin{array}{r}23.66 \\
2.75 \\
19.71\end{array}$ & $\begin{array}{c}19.04 \\
5.13 \\
14.6\end{array}$ \\
\hline $\begin{array}{l}\text { Goggle } \\
\text { eye }\end{array}$ & $\begin{array}{l}\text { Protein } \\
\text { Ash } \\
\text { Lipid }\end{array}$ & $\begin{array}{r}19.85 \\
2.24 \\
10.37\end{array}$ & $\begin{array}{r}23.24 \\
4.42 \\
11.51\end{array}$ & $\begin{array}{r}22.28 \\
2.51 \\
12.30\end{array}$ & $\begin{array}{r}18.50 \\
2.02 \\
9.51\end{array}$ \\
\hline $\begin{array}{l}\text { Gold } \\
\text { Fish }\end{array}$ & $\begin{array}{l}\text { Protein } \\
\text { Ash } \\
\text { Lipid }\end{array}$ & $\begin{array}{c}17.99 \\
2.8 \\
14.69\end{array}$ & $\begin{array}{c}21.16 \\
7.5 \\
15.20\end{array}$ & $\begin{array}{r}20.26 \\
1.91 \\
15.41\end{array}$ & $\begin{array}{c}15.62 \\
4.58 \\
10.3\end{array}$ \\
\hline $\begin{array}{l}\text { Rosy } \\
\text { barb }\end{array}$ & $\begin{array}{l}\text { Protein } \\
\text { Ash } \\
\text { Fat }\end{array}$ & $\begin{array}{r}20.01 \\
4.01 \\
7.98\end{array}$ & $\begin{array}{r}20.43 \\
3.85 \\
11.92\end{array}$ & $\begin{array}{r}25.50 \\
3.35 \\
12.50\end{array}$ & $\begin{array}{c}17.59 \\
3.61 \\
7.4\end{array}$ \\
\hline
\end{tabular}


Table VI.1 Growth of Angels fed with four different feeds

$$
\begin{aligned}
& \text { F1 - } 44 \% \text { protein, } \quad \text { F2 - 50\% protein } \\
& \text { F3 - 62\% protein, F4 - 32\% protein }
\end{aligned}
$$

\begin{tabular}{lcccc}
\hline \multirow{2}{*}{$\begin{array}{l}\text { Growth } \\
\text { parameter }\end{array}$} & \multicolumn{4}{c}{ Feeds } \\
\cline { 2 - 5 } & Feed F1 & Feed F2 & Feed F3 & Feed F4 \\
\hline Initial Wt. (g) & 0.09 & 0.09 & 0.03 & 0.09 \\
Wt. after 2 months (g) & 0.55 & 0.72 & 0.51 & 0.46 \\
Gain in Wt. (g) & 0.46 & 0.63 & 0.48 & 0.37 \\
Initial SL (cm.) & 1.13 & 1.15 & 0.97 & 1.13 \\
SL (cm) after 2 months & 2.11 & 2.24 & 2.11 & 1.85 \\
Tot. Food Consn (g) & 0.73 & 0.73 & 0.586 & 0.727 \\
Tot. Faecal output (g) & 0.31 & 0.32 & 0.19 & 0.2 \\
Growth per Day (g) & 0.008 & 0.010 & 0.008 & 0.006 \\
Assimilation Efficiency & $57 \%$ & $56 \%$ & $68 \%$ & $72 \%$ \\
Consumpn (g) Day-1 & 0.01 & 0.01 & 0.01 & 0.01 \\
Focd Conversion Ratio & 1.58 & 1.15 & 1.21 & 1.96 \\
Feacal Output as a \% & $43 \%$ & $44 \%$ & $32 \%$ & $28 \%$ \\
of Consumption & & & & \\
Survival Rate & $93 \%$ & $100 \%$ & $93 \%$ & $93 \%$ \\
\hline
\end{tabular}

Table VI.2 Growth of Goggle-eye fed with four different diets

$$
\begin{array}{llll}
\text { F1 } 1-44 \% & \text { protein, } & \text { F2- } 50 \% & \text { protein } \\
\text { F3 }-62 \% & \text { protein, } & \text { F4 } 32 \% & \text { protein }
\end{array}
$$

\begin{tabular}{lllll}
\hline & \multicolumn{5}{c}{ Feed } \\
\cline { 2 - 5 } Growth parameter & $F 1$ & $F 2$ & $F 3$ & $F 4$ \\
\hline Initial Wt. (g) & 0.19 & 0.19 & 0.19 & 0.19 \\
Wt. after 2 months (g) & 1.25 & 1.58 & 1.49 & 1.1 \\
Gain in Wt. (g) & 1.06 & 1.39 & 1.30 & 0.82 \\
SL (Initial) (cm) & 1.50 & 1.29 & 1.28 & 1.29 \\
SL (cm) after 2 months & 3.70 & 2.85 & 2.91 & 2.49 \\
Tot. Food Cons ${ }^{n}$ (g) & 1.36 & 1.36 & 1.36 & 1.36 \\
Tot. Faecal output (g) & 0.37 & 0.33 & 0.26 & 0.23 \\
Growth per Day (g) & 0.019 & 0.022 & 0.021 & 0.013 \\
Assimilation Efficiency & $73 \%$ & $75 \%$ & $81 \%$ & $85 \%$ \\
Consum ${ }^{n}$ (g) Day- ${ }^{-1}$ & 0.02 & 0.02 & 0.02 & 0.02 \\
Focd Conversion & 1.28 & 0.98 & 1.05 & 1.66 \\
Ratio (FCR) & & & & \\
Feacal Output as $\%$ & $26 \%$ & $24 \%$ & $19 \%$ & $16 \%$ \\
of Consumption & & & & \\
Survival Rate & $100 \%$ & $100 \%$ & $100 \%$ & $97 \%$ \\
\hline
\end{tabular}


Table V1.3 Growth of Gold fish fed with four different feeds

\begin{tabular}{lllll}
\multicolumn{1}{r}{ F1 $-44 \%$} & protein, & F2 $-50 \%$ & protein \\
p3 $-62 \%$ & protein, & F4 $-32 \%$ & protein \\
\hline & \multicolumn{4}{c}{ Feed } \\
\cline { 2 - 5 } Growth parameter & $F 1$ & $F 2$ & $F 3$ & $F 4$ \\
\hline Initial Wt. (g) & 0.05 & 0.05 & 0.05 & 0.05 \\
Wt. after 2 months (g) & 1.36 & 1.33 & 1.99 & 0.93 \\
Gain in Wt. (g) & 1.33 & 1.27 & 0.95 & 0.88 \\
SL. initial (cm) & 0.83 & 0.83 & 0.83 & 0.83 \\
SL(cm) after 2 months & 2.59 & 2.61 & 2.61 & 2.25 \\
Total Food Consum- & 1.11 & 1.11 & 1.11 & 1.11 \\
$\quad$ ption (g) & & & & \\
Total Faecal output (g) & 0.25 & 0.20 & 0.20 & 0.18 \\
Growth per Day (g) & 0.021 & 0.020 & 0.014 & 0.014 \\
Consum (g) Day-1 & 0.54 & 0.54 & 0.54 & 0.54 \\
Assimilation Efficiency & $78 \%$ & $82 \%$ & $82 \%$ & $84 \%$ \\
Food Conversion & 0.83 & 0.87 & 0.85 & 1.2 \\
Ratio (FCR) & & & & \\
Faecal Output as $\%$ & $23 \%$ & $18 \%$ & $18 \%$ & $16 \%$ \\
of Consumption & & & & \\
Survival Rate & $96 \%$ & $96 \%$ & $100 \%$ & $93 \%$ \\
\hline
\end{tabular}

Table VI.4 Growth of Rosy barbs fed with four different feeds.

$$
\begin{aligned}
& \text { F1 - } 44 \% \text { protein, F2 - 50\% protein } \\
& \text { F3 - 62\% protein, F4 - 32\% protein }
\end{aligned}
$$

\begin{tabular}{lllll}
\hline \multirow{2}{*}{ Growth parameter } & \multicolumn{4}{c}{ Feed } \\
\cline { 2 - 5 } & \multicolumn{1}{c}{$F 1$} & \multicolumn{1}{c}{$F 2$} & $F 3$ & \multicolumn{1}{c}{$F 4$} \\
\hline Initial Wt. (g) & 0.08 & 0.08 & 0.71 & 0.08 \\
Wt. after 2 months (g) & 0.47 & 0.47 & 1.48 & 0.33 \\
Wt. gain (g) & 0.39 & 0.39 & 0.77 & 0.25 \\
SL Initial (cm) & 1.0 & 1.0 & 2.38 & 1.0 \\
SL after 2 months (cm) & 1.99 & 2.18 & 3.46 & 1.75 \\
Total Food Consum- & 0.73 & 0.73 & 2.88 & 0.73 \\
ption (g) & & & & \\
Tot. Faecal output (g) & 0.20 & 0.19 & 0.62 & $0.1 s$ \\
Growth per Day (g) & 0.007 & 0.006 & 0.012 & 0.004 \\
Assimilation Efficiency & $73 \%$ & $74 \%$ & $81 \%$ & $81 \%$ \\
Consum (g) Day-1 & 0.012 & 0.012 & 0.046 & 0.012 \\
Focd Conversion & 1.86 & 1.89 & 3.76 & 2.93 \\
Ratio (FCR) & & & & \\
Faecal Output as\% & $27 \%$ & $26 \%$ & $22 \%$ & $19 \%$ \\
of Consumption & & & & \\
Survival Rate & $97 \%$ & $97 \%$ & $97 \%$ & $97 \%$ \\
\hline
\end{tabular}


Table VII. Costs of feeds

\begin{tabular}{ccccc}
\hline Feed & $F 1$ & $F 2$ & $F 3$ & $F 4$ \\
\hline $\begin{array}{c}\text { Cost } / \mathrm{kg} \\
\text { (Rs.) }\end{array}$ & 51.00 & 57.00 & 33.00 & 240.00 \\
\hline
\end{tabular}

\section{Results and Discussion}

High Assimilation Efficiencies (AE) $(>50 \%$ ) indicate that the food was in readily assimilable form and little was lost as faeces. Assimilation Efficiencies of fish fed on the three laboratory prepared feeds in the present study were high in the range of $56 \%-82 \%$ (Tables VI.1-VI.4) showing that they were in readily assimilable form and well accepted by fish. These Assimilation Efficiencies are also comparable with that of commercial feed tested $(72 \%-85 \%)$ (Tables VI.1-VI.4) and also with that of various fish species fed on Artemia $(59 \%-96 \%)$ (Vijayaraghavan et.al., 1985).

High Food Conversion values correlate with very low growth rates thereby indicating that the fish have not responded well to the feeds. Food varieties giving food conversion values less than 3 are considered as well accepted and commonly used food in aquaculture (Bardach et. al.,1972). It has also been recorded that diets which are poorly digested by the fish or low in protein will produce Food Conversion Ratios of 2 or more (Shepherd and Bromage, 1988). In the present study fish have generally shown low Food Conversion Ratios (less than 2) for all three laboratory prepared feeds (Tables VI.1-VI.4). This further confirms that the fish have responded well to these feeds.

Growth rates reported for all four species fed on three laboratory prepared feeds were in the range of $0.005-0.02 \mathrm{~g}$. day- ${ }^{1}$ (Tables VI.1-VI.4) and these were higher than the growth rates achieved by the same species fed on commercial feed F4 (0.004-0.01g.day- $\left.{ }^{1}\right)$ as well as the same and other species fed on Artemia (0.0007-0.01g. day- ${ }^{1}$ ) (Vijayaragavan et. al.,1985). These results and the high survival rates $(93 \%-100 \%)$ (Tables VI.1-VI.4) achieved by the fish species fed on the feeds also suggest that these low cost feeds can be easily used for fry/fingerling stages of Angels, Rosy barbs, Goggle eyes and Gold fish. 
In the present study, there was a significant increase $(P<0.05)$ in growth rates of all other species except Rosy barb with the increase in dietary protein level upto $44-50 \%$ and above that level they either showed a significant decrease of growth rate or did not show any significant difference in the growth rate (Fig.1). Similar observations have been made in previous studies where the young of several other warm water fish species such as Tilapia zilli (Muzid et. al., 1979) Nile tilapia (Oreochromis nilotica) (Santiago et. al., 1982), and gray mullet (Mugil cephulus) (Papoutsoglou and Alexis, 1986) have manifested growth depressions in response to excessive level of dietary protein content when approximately isocaloric diets were tested. Results of the present study and previous studies therefore suggest that there is an optimal level of dietary protein requirement and according to the present study it is in the range of $44-50 \%$ for all species but Rosy barbs tested. However, the dietary protein requirement of some of the edible forms have been lower than this range. For instance, the optimal level of common carp (Cyprinus carpio) fry is $35 \%$ (Sen et. al., 1978) and $38 \%$ for fingerlings (Ogino and Saito, 1970) and $35 \%$ for Rabbit fish, Siganus guttatus (Parazo, 1990).

Growth rates of Rosy barbs with different protein levels cannot be compared because the Rosy barbs used to test feed F2 were bigger in size.

When protein content of feeds increased more than $50 \%$, muscle protein level decreased for all fish species but Rosy barbs (Table IV and V). This further confirms that a very high protein content in feed is not necessary for the optimal growth and there is an optimal requirement of protein for optimal growth of fish and this has been revealed earlier in other studies (Vijayaraghavan et. al, 1985). Here again comparison of muscle protein level of Rosy barbs is impossible due to size difference of fish used in testing feed F2 with that of other feeds.

Cost of feeds is an important aspect for all aqua-culturists. In the present experiment, cost for all three experimental feeds were lower than the commercial feed (Table VII). Main factor attributed for low cost of feeds in the present study was the use of low cost protein sources (eg: shrimp heads, fish/meat offals, plant matter such as carrot leaves and Ipil ipil, rice bran, soya flour). Soya flour utilization in fish diets as a source of protein has increased recently due to its nutritional quality and low cost (Akiyama, 1988).

Results obtained in the present study also show that the fish fed on diet $\mathrm{F}_{3}$ with high protein $(62 \%)$ and low carbohydrates $(8 \%)$ showed low retention of protein in their body muscles while fish fed on moderate protein and high carbohydrates (eg: Feed $F_{1}$ with $44 \%$ protein and $11 \%$ carbohydrate, $F_{2}$ with $50 \%$ protein-14\% carbohydrate) (Table IV, V) had retained more proteins in their body muscles than the above. Similar observation has been made on eels (Degani and Viola, 1987). This shows that the use of more carbohydrates and less protein in diets helps in retaining more protein in body muscles while it is also useful in reducing the feed cost. 
Regular monitoring of temperature, $\mathrm{pH}$, total hardness and dissolved oxygen showed satisfactory water quality in the experimental tanks (Table III). This shows that the feeds tested do not affect the quality of water which again is an important quality of an artificial feed.

Experimental feeds also had long shelf-life (over 6 months) in sealed packets and air-tight containers under refrigeration and room temperature (Table II). They could even be kept unspoilt in open containers in room temperature and under refrigeration for 7-18 days and 28-60 days respectively (Table II). This also fulfils another quality expected of artificial feed; to be able to be kept unspoilt for long periods.

The procedure used to make the feeds included steaming them for five minutes and drying them well (Appendix I). These may have helped to avoid any fungal attacks or formation of any other organisms responsible for spoilage of food ensuring a long shelf life.

\section{Acknowledgements}

The authors wish to thank the University of Sri Jayewardenepura for

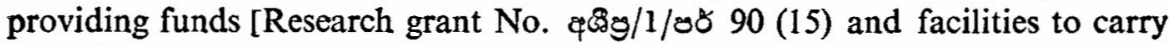
out the above research work.

\section{References}

Akiyama D. 1988., Soybean meal utilization by marine shrimp. Paper presented at the AOCS World Congress on vegetable Protein Utilization in Human Food and Animal Feedstuffs. Singapore. 2-7 Oct. 1988. Am. Soybean Assoc, 27pp.

Annonymous (1990). The Globle trade in Ornamental fish and Sri Lanka's potential, Business Lanka, 9 (1), 1990 March,

Annonymous (1992). Directory of the Association of live fish exporters of Sri Lanka. Published for the Exhibition and Conference held on 18.22 Nov. 1992 at the BMICH, Colombo.

Balley N.T.J. (1965). Statistical methods in Biology, Printed in Great Britain.

Bardach, J.E., J.H. Ryther, W.O. and Mclarney (1972). Aquaculture:The farming and Husbandary of freshwater and Marine Organisms. Printed by John Wiley and Sons: 46-47.

Brohmanonda, P and S. Shavacharin (1984). Macrobrachium culture SAFIS Manual, Published by the South East Asian Fisheries Development Centre, Vol. 8 :15p.

Chandrasoma J. and P. P. G. S. N. Siriwardene (1988). Effect of the dietary protein level on growth and survival of Labeo rohito (Ham) fry. Journal Inland Fisheries, Vol 41 December 1985: 17-23.

Clark A. E., W. O. Watanabe, B. L. Oila and R. Wickland (1989), Growth, feed conversion and protein utilization of Florida red Tilapia fed iso caloric diets with different protein levels on seawater pools. Aquaculture, 88 (1990) 75-85.

De Alwis, A., S. Jayamanne and A. Perera (1988). Brackishwater Prawn culture (in sinhala). A hand book published by the National Aquatic Resources Agency of Sri Lanka: 43p. 
Degani, G. and Viola, B. 1987. Protein sparing effect of carbohydrate in the diet of cels (Anguilla anguilla). Aquaculture. 64: 283-291.

De Silva S. S. and M. K. Perera, (1985) : Effects of Dietary protein level on growth, food conversion and protein use in young Tilapia Nilotica at four salinities. Reprinted from Transactions of the American Fisheries Society, 114 (4) July (1985) : 584-589.

Muzid, M. A. Tanaka, Y., Katayama, T. Rahman, M.A., Simpson, K.L. and Chichester,

C.O., 1979. Growth response of Tilapia Zilli fingerlings fed isocaloric diets with variable protein levels. Aquaculture. 18: 115-122.

Ogino, C. and Saito K., 1970. Protein nutrition. The utilization of dietary protein by young carp. Buil.Jpn. Soc. Sci. fish., 36: 250.254 (English translation by Lydia A. Hutchinson, Universities Translation Service, San Diego, CA)

Papoutsoglou, P. E. and Alexis, M.N., 1986. Protein requirements of young grey mullet, Mugil capito. Aquaculture, 52: 105-115.

Parazo M. M. (1990) : Effects of dietary protein and energy level on Growth, protein utili zation and carcass composition of Rabbit fish Siganus guttatus. Aquaculture, 86 (1980): 41-49.

Primavera, J. H. (1982). Brood stock of sugpo (Penaeus monodon Fabricus). Aquaculture Extension Manual, SEAFDEC Publication, Vol. 7: 24p.

Santiago, C. B., Aldaba, M.B. and Laron, M.A., 1982. Dietary crude protein reqirement of Tilapia Nilotica fry. Kalikasan, Philipp J. Biol. 11 (2\&3) :61-71.

Sen, R. R., Rao, N. G. S., Ghosh, G. R., Rout, M., 1978. Observations on the protein and carbohydrate requirements of carps. Aquaculture, 13: (119-127).

Vijayaraghavan S., M. M. Kuruppu, K. J. Grero and A. Perera. 1985 Growth assessment in some ornamental fishes fed with different feeds. NARA Technical Paper 5: 58-77.

Zar J.H. (1974), Bio statistical analysis, Prentis-Hall Publications; 163-176.

\section{Appendix 1}

\section{Procedure for feed preparation}

Two varieties of plant leaves; Ipil ipil (Leucaena leucocephala, and Carrot leaves (Daucuspu carota) were used to make the feeds $F_{1}$ and $F_{2}$ respectively. The leaves were dried at $40^{\circ} \mathrm{C}$ in an oven, ground and sieved with a domestic sieve.

Shrimp-heads were well washed and boiled till their colour became light orange. Then these were dried at $60^{\circ} \mathrm{C}$, ground and seived. Multivitamin, Vitamin C, yeast tablets, and poonace were ground well. Meat-offals were minced.

All ingredients were mixed well in a large bowl and a stiff dough was prepared using water. Cod liver oil was added gradually to the dough while mixing.

Pellets (of length approximately half a centimetre and $3 \mathrm{~mm}$ diameter) were made out of this stiff dough, using the mincer. These pellets were steamed for 5 minutes and dried in an oven at $60^{\circ} \mathrm{C}$ over night, till the pellets were well dried. Bulk feed was stored in air tight plastic jars. 
Appendix II

Costs of raw materials (given on per kilo basis)

Meat offal (wet)

Rs. per kilo

Fish meal

$25 /-$

Shrimp head

Rice bran

$8 /-$

Soya flour

Wheat flour

Carrot leaves

Ipil ipil

Mineral mixture

Yeast

free of charge

$3 /-$

29/-

$15 /-$

free of charge

free of charge

$48 /-$

Multivitamin

Vit.C

50 cents a tablet

24 cents a tablet

10 cents a tablet

Vit.E

1 - a tablet

Cod liver oil

20 cents a capsule

Poonac

$6 /-$

Fish liver (wet)

Labour cost

Transport cost

$30 /-$

10/- per kilo of feed

5/ per kilo of feed

Electricity cost

$5 /-$ per kilo of feed 